\title{
Results of growing parsley using aquaponics method
}

\author{
Denis Yurin ${ }^{1 *}$, Natalya Yurina ${ }^{1,2}$, Gayanje Arutyunova ${ }^{3}$, Ekaterina Maxim ${ }^{1}$, and Boris \\ Khorin $^{1}$ \\ ${ }^{1}$ Krasnodar Research Centre for Animal Husbandry and Veterinary Medicine, 350055, Krasnodar, \\ Russian Federation \\ ${ }^{2}$ Kuban State Agrarian University named after I.T. Trubilin, 350000, Krasnodar, Russian Federation \\ ${ }^{3}$ Maykop State Technological University, 385000, Maykop, Republic of Adygea, Russian Federation
}

\begin{abstract}
The article presents the results of experiments on the use of the aquaponics method. Aquatic animals release products toxic to them themselves: nitrogenous, phosphorus, potassium compounds, carbon dioxide. The accumulation of these substances in water is the main problem as in closed industrial aquaculture. The same substances are absolutely necessary in hydroponics and they are added to water to obtain nutrient solutions for plants. Given that environmentally friendly products are increasingly popular and demand for them is constantly growing, there are prospects for introducing this innovation in the southern regions of Russia. Due to an increase in parsley yields in the aquaponic plant by $7.3 \%$, an additional profit was received 4.8 rubles from 1 square meters.
\end{abstract}

\section{Introduction}

In the conditions of intensification of sturgeon growing and growing fish in pools [1], the synergy of industries in the form of fish farming and aquaponics is appropriate.

Joint cultivation of fish and plants is a modern direction, in the conduct of which it is possible to obtain high-quality food products, while conducting profitable business for small enterprises. The increase in the profitability of the enterprise is due to the fact that fish and grown plants have similar needs for energy and heat costs [2-4].

In industrial conditions, using intensive technologies [5-7] and maintaining fish in pools with closed water supply, biogens accumulate in the process of fish life. Their oxidation, as well as the remaining feed, leads to an increase in the number of nitrogen exchange products $[8,9]$.

Ammonium, nitrites, nitrates can be used as nutrients in growing various plants: tomatoes, cucumbers, basil, lettuce and other crops, as well as greens [10-12].

Today, aquaponics is a promising method of growing plants without soil from the point of view of combining the technology of intensive sturgeon breeding and crop production, since at the exit a complex of environmentally safe fish production and crop production is obtained. The quality of products obtained using aquaponics technology is evaluated by the chemical composition of aquaponic plants, the absence of toxic substances in them, the

*Corresponding author: 4806144@mail.ru 
amount of oxygen released to wastewater and the number of biogens consumed. However, sturgeon breeding is not limited to basin content, and is often combined with pond fish farming [13-16]. Therefore, we have made attempts to combine pond fish farming (aquaculture) with the cultivation of plants without soil (hydroponics) on the surface of the reservoir.

\section{Methodology}

The purpose of the studies was a comparative analysis of the cultivation of parsley greens in soil and in a water plant.

The following tasks were set and solved:

1) to determine the yield of plants in different methods of cultivation;

2) perform analysis of dry substance content in greens;

3) calculate the economic effect of aquaponics.

Subject of the study: parsley seeds grown in soil and groundless environment.

Object of investigation: soil and aquaponic installation.

The hypothesis of the study is represented by the assumption that the cultivation of parsley seeds in a pontoon aquaponic plant is low-cost and fast.

LLC “Albashi” is an enterprise engaged in the breeding and cultivation of pond fish and sturgeon in pools and gardens, crayfish, and the cultivation of aquaponic greens. Basil, green onions, dill, parsley are grown from aquaponic greens in the farm.

Basil. Basil cultivation can be carried out from April to September. Basil is excellent for growing in a lemnoponic plant, due to the fact that its root system develops perfectly in water. This plant has a high growth rate in a lemnoponic plant, while its taste and aroma are not inferior to plants grown in the ground. Pre-soaked basil seeds are germinated directly in pots of a lemnoponic plant or separately. Intensive plant growth begins from the second week after germination. The first cut of the basil in the lemnoponic plant can be made on the 26-30th day.

Green onion is the easiest way to grow onions on a green feather of racing varieties (Rostovsky, Strigunovsky, Spassky) or onion sets. To do this, you need to select small bulbs with a diameter of 3-4 centimeters. For a faster appearance of the feather, you can trim the bulb neck. In the first 2-3 days, the onion actively develops the root system. The pen can be cut when it reaches 15-17 centimeters or more. The period for which the greens reach this height is 14-16 days.

Dill. Dill seeds, when grown in a lemnoponic plant under the conditions of LLC "Albashi", were planted directly into cups, with further installation in platforms and placement on water smoothness. Two varieties of dill "Alligator" and "Gribovsky" were chosen. Planted in a lemnoponic plant for comparison on April 25, 2020.

Parsley. Comparative sowing of "Italian Giant" parsley was carried out in the soil, and in the developed aquaponic device.

Studies were carried out in the conditions of LLC “Albashi” from May 20, 2020. Repetition is quadruple. Sown quality of seeds and yield were determined according to the method of B.A. Dospekhov (1985), biometric data - according to the Methodology of experimental work in vegetable and melon growing /Ed. V.F. Belika. M.: Agropromizdat, 1992. 312 p. Weeding was carried out in soil and cups as necessary. The first group (control) is the planting of parsley seeds in the ground (sowing was carried out subject to the distance between plants - 30 centimeters), the second group is the planting of seeds in an aquaponic device (Table 1). 
Table 1. Scheme of the experiment

\begin{tabular}{|c|c|}
\hline Group & Experiment scheme \\
\hline 1 & $\begin{array}{c}\text { Control - planting parsley seeds in the ground (sowing } \\
\text { was carried out while observing the distance between } \\
\text { plants - 30 centimeters) }\end{array}$ \\
\hline 2 & $\begin{array}{c}\text { Experience - planting seeds in an aquaponic device in } \\
\text { cups }\end{array}$ \\
\hline
\end{tabular}

Parsley seeds were planted into the soil on experimental plots with an area of 5 sq.m. on chernozem leached from the $\mathrm{pH}$ of salt extract (determination by $\mathrm{pH}$-meter Expert-pH (3x1) $6.3 \pm 0.2$, with the content of mobile phosphorus (GOST 26205-91) - $17.0 \pm$ $3.0 \mathrm{mg} / \mathrm{kg}$, mobile potassium (GOST 26205-91) - $323.0 \pm 33.0 \mathrm{mg} / \mathrm{kg}$, humus (GOST 26213-91) - 3.21\%, exchange ammonium (GOST 26489-85) - $2.5 \pm 0.5 \mathrm{mg} / \mathrm{kg}$, nitrates (IPA F 16.1: 2: 2.3: 2.2.69-10) - $16.5 \pm 1.2 \mathrm{mg} / \mathrm{kg}$ per $100 \mathrm{~g}$ of soil. Sowing was carried out subject to the distance between plants - $30 \mathrm{~cm}$, planting depth $-1 \mathrm{~cm}$, the number of seeds at the rate of 0.5 g per 1 sq.m. Soil parsley was periodically watered with permanent water in the evening hours after sunset. Mineral fertilizers were introduced (g per $1 \mathrm{~m}$ ): after the appearance of seedlings, ammonium nitrate - 10 and superphosphate - 5 .

For measurements, 30 plants were taken. For biochemical analysis, 6 samples were taken from each group. Content of solid was determined using an Evlas 2M device, the amount of nitrates was determined by the ionometric method. The economic justification was calculated based on the cost of products using the studied technologies. Statistical processing was performed using Microsoft Excel. Differences were considered valid at $\mathrm{p}<0.05 ; \mathrm{p}<0.01 ; \mathrm{p}<0.001$, relative to the first group.

The developed aquaponic device comprises a pool for fish (sturgeon) and a plant growing device, which is made in the form of a cylinder with holes, located in rows along its entire length and at a distance from each other, to ensure their location in tiers at an acute angle relative to the horizontal plane of the modules. The latter are made of perforated pots with neutral porous soil, in our case coconut flakes, in which plants are planted.

The use of an aquaponic device provides favorable conditions for growing plants and fish with a significant decrease in the cost of mounting the structure and its maintenance costs.

\section{Results and discussion}

During the experiment, it was established that the seeds of the Italian Giant variety germinated in the aquaponic installation faster than in the ground: seedlings appeared in both installations on the 7th day. When landing in the ground, seedlings appeared on the day 14 . Seed germination in the first group was $62.0 \%$, in the second - $66.0 \%$. The growing season from seedlings to parsley harvest was 60 days in all groups. Parsley in the ground had dark green leaves, in the aquaponic installation the color of parsley leaves was also not inferior to soil, which is associated with the use of a removable roof in the fish module (PM No. 198402), where the aquaponic installation was located.

The yield of greens at the first cut was $0.436 \mathrm{~kg}$ in the first group from 1 square meters.

In the aquaponic plant in the second group, the yield from 1 sq.m. was $0.503 \mathrm{~kg}$ from 1 sq.m., which is higher than the control by $15.4 \%$.

The length of the plants was almost the same in all groups without any special differences and varied within 42 centimeters. The mass of the roots was in plants of the first group $8.4 \pm 0.2 \mathrm{~g}$, the second group $-8.1 \pm 0.1 \mathrm{~g}$ without a reliably significant difference (Table 2). 
Table 2. Plant length and dry matter content, $\mathrm{n}=30$

\begin{tabular}{|c|c|c|}
\hline \multirow{2}{*}{ Indicators } & $\mathbf{2}$ & Group \\
\cline { 2 - 3 } & $\mathbf{1}$ & $\mathbf{2}$ \\
\hline $\begin{array}{c}\text { Mass of plants, } \\
\text { cm }\end{array}$ & $42,0 \pm 1,2$ & $42,4 \pm 1,0$ \\
\hline Plant length, cm & $8,4 \pm 0,2$ & $8,1 \pm 0,1$ \\
\hline $\begin{array}{c}\text { Yield for the } \\
\text { whole cycle, } \mathrm{kg}\end{array}$ & 1,65 & 1,77 \\
\hline $\begin{array}{c}\text { Dry matter } \\
\text { content in } \\
\text { parsley, } \%\end{array}$ & $16,5 \pm 0,4$ & $12,6 \pm 0,5$ \\
\hline
\end{tabular}

In total, the yield of parsley for the entire cycle (3 sections) was $1.65 \mathrm{~kg}$ in control, in the second group: $1.77 \mathrm{~kg}$, which is $7.3 \%$ higher.

The content of dry matter in the green mass $(n=6)$ of parsley of the first group was $16.5 \pm 0.4 \%$, of the second group - $12.6 \pm 0.5 \%(\mathrm{p}<0,001)$. Therefore, in the aquaponic method of cultivating parsley, the content of dry matter in the green mass is significantly reduced by $3.9 \%$. However, when tasting products, no special differences were found in the aroma and taste of greens between groups.

Despite the decrease in dry matter in parsley, the aquaponic method is presented as an alternative to primer, and in no case, we recommend to replace it. This method can be used as an additional crop production in fish breeding, in this case sturgeon.

The nitrate content of the second group of plants was at the same level as the control. Toxic substances in plants of all groups were significantly lower than the maximum allowable concentration values.

With a cost of cultivation of parsley in the soil of 60 rubles. in terms of $1 \mathrm{~kg}$ of green mass, the price of its sale amounted to 120 rubles for $1 \mathrm{~kg}$, therefore, the profit was equal to 60 rubles.

With the cost of cultivating parsley in a water plant of 60 rubles (due to overhead costs for the use of electricity to ensure the vital activities of sturgeon fish in pools) per $1 \mathrm{~kg}$ of green mass, the price of its sale amounted to 120 rubles for $1 \mathrm{~kg}$, therefore, profit was equal to the same 60 rubles.

Due to an increase in parsley yields in the aquaponic plant by $7.3 \%$, an additional profit was received 4.8 rubles from 1 square meters.

The purpose of the product is to be sold through the retail network or by wholesale sales. This is an additional profit for the enterprise and a more rational use of water smoothness is an excellent way to conduct water management.

The products are environmentally safe, without the use of growth stimulants, pesticides, herbicides and insecticides. The sale of crop products grown in an aquaponic plant will cover the costs of the fish breeding enterprise for fuel and lubricants, wages for workers, and electricity. Thus, fish farming products also reduce their cost.

An important factor in the current geopolitical situation and pandemic conditions is the provision of the population with products from the production of enterprises in their region, which reduces logistics costs, allows you to get the finished product for consumption directly "from field to plate" and reduces the cost. This is a social factor, deliveries to children's institutions, nursing homes, schools are possible, and further developments in the use of aquaponic crop products in the production of baby food are also possible.

With excess production, or the absence of part of the sale, it is possible to preserve and dry plants, which increases their shelf life and sale. 


\section{Conclusions}

The main advantage of the aquaponics method, based on the combination of two technologies, is that fisheries and aquaponics can almost completely get rid of the waste of both systems, forming a closed ecosystem in which fish emissions are absorbed by plants, feeding them, and the water where fish live is cleaned by plants. Due to an increase in parsley yields in the aquaponic plant by $7.3 \%$, an additional profit was received 4.8 rubles from 1 square meters.

Thus, the joint cultivation of plants and fish has future development prospects as agricultural innovation, and will be able to provide the food market with environmentally safe crop production and fish, both in Russia and anywhere in the world.

Summing up, it should be noted that hydroponics, aquaponics deserve the closest attention. These methods save land and water resources, control each stage of biotechnology cultivation and produce a large mass of plant and fish products.

\section{References}

1. V.G. Krymov, D.A. Yurin, S.I. Kononenko, E.A. Maxim, N.A. Yurina. Int. J. of Pharmac. Res., 10(4), 316-322 (2018)

2. VA. Grigoriev, A.V. Kovalyova, M.N. Sorokina, Natural sci., 4(53), 96-101 (2015)

3. A.V. Kovrigin, V.P. Kamenko, R.A. Isayev. Belgorodsky agromir, 3, 8-10 (2015)

4. N.V. Kuryleva, A.V. Yurina. Youth and sci., 5, 69 (2016)

5. N.N. Mamasya, O.V. Ryabtseva, E.V. Solodovnik. Sci. J. of KubGAU, 83(09), 15, (2012)

6. I.S. Belyuchenko. Sci. J. KubGAU, 106(02), 22, (2015)

7. M.L. Gordievsky, E.I. Kolovaya, V.V. Evchenko. APK of Russ., 73, 129-133 (2015)

8. S.E. Boxman, S.J. Ergas and M.A. Trotz. Ecological Engineering, 120, 299-310 (2018)

9. N.A. Yurina, A.G. Koshchaev, D.V. Osepchuk, E.A. Maksim, A.A. Danilova, D.V. Shumeiko. Int. J. of Engineer. and Advan. Technol., 9(1), 4957-4960 (2019)

10. S. Mustafa, R. Shapawi, Aquaculture ecosystems: adaptability and sustainability (Wiley-Blackwell, 2015)

11. A. Greenfeld, N. Becker, J.F. Bornman, M.J.Santos, D. Ange. J. of Environmental Manag., 257, 109979 (2020)

12. A. Cohen, S. Malone, Z. Morris, M. Weissburg, B. Bras. Procedia CIRP, 69, 551-556, (2018)

13. N.E. Tregubova. Young sci., 33(167), 68-71 (2017).

14. N.A Yurina, D.A. Yurin, E.A. Maxim, A.A. Danilova, I.R. Tletseruk. Amazonia Investiga, 9(25), 279-284 (2020)

15. O.V. Bayanova, S.L Maksimova, Methods of research activity on ecology (for heads of associations of ecological-biological and natural science. (GAU DOD TO "OTSDODM". Tyumen, 2013)

16. Zemskova Yu.K. Methods of research in vegetable growing: lecture course (FGBOU VPO "Saratov GAU". Saratov, 2014) 